\title{
Marketing Analysis of Political Positioning in Legislatif Election
}

\author{
AMA Suyanto ${ }^{1, *} \&$ M Yahya Arwiyah ${ }^{2}$ \\ ${ }^{1}$ School of Economic and Business, Telkom University, Bandung, Indonesia \\ ${ }^{2}$ School of Business Administration, Telkom University, Bandung, Indonesia \\ *Correspondence: Telkom University, Jl Telekomunikasi No 1 Trs Buah Batu, Bandung, Indonesia. Tel: \\ 62-811-147-874. E-mail: ama@telkomuniversity.ac.id; amasuyanto@gmail.com
}

Received: July 1, 2015

doi:10.5430/mos.v2n4p16
Accepted: August 21, $2015 \quad$ Online Published: September 16, 2015

URL: http://dx.doi.org/10.5430/mos.v2n4p16

\begin{abstract}
Legislative election in 2014 is the direct election of legislative candidates in district, provincial and national region. The purpose of this study is to analyze the political positioning based on regional aspects. The method used was descriptive qualitative, with the objects of study were the community, legislative candidates and members of the General Election Commissions (KPU) in rural area rural area and commuter area. The techniques of collecting data was in-depth interviews, field observations in the community, data documentations of legislative candidates, data of voters, electronic documentations, and questionnaires. Validation of the data was using triangulation of data between the interviews data, observations data, documentation data and questionnaires data. Data analysis technique used the interactive model analysis that consists of data preparation analysis, data sorting analysis, digging deep meaning to the data, presenting the data and create a broader interpretation of the meaning of the data. The results obtained that: the political marketing strategy used by political parties and their promoted candidates were in the form of combination between pull political marketing approach which is synergized with push political marketing approach. In rural area, political marketing strategy by political parties and their promoted candidates find to use push political marketing approach. Legislative election political positioning in commuter area turn out to be based on rational-emotional while in rural area based on emotional choices. This study is practically implicated that political market positioning can determine voters' decisions appropriately. While the theoretical implications is increasing repertoire of social sciences, particularly complementing between political science, marketing science and civic education so as to create a civil society.
\end{abstract}

Keywords: marketing politic; legislative election; political positioning

\section{Introduction}

In 2014, Indonesia has implemented Democratic Party to determine the Indonesian leader for the next five years, especially the legislature. The success of the 2014 elections is a measure of the progress of democracy. Constituents must be really smart to make their choice, the victory of a political actor is also determined by undertaken political marketing strategy (Suyanto, et al; 2014: 455). Political marketing must contain political education towards the public as a function of a political party that led to the civil society, not only to sell the candidates with the main objective to get the votes. Political education is one of the responsibilities of political parties, contained in Article 6 and Article 7 of Law No. 31 of 2002 on political parties. Alfian (1978: 235), political education can be understood as a process of socialization to internalize the values that are considered ideal and needs to be fought, the achievements of the process is in the form of political attitudes and behaviors which are oriented on the efforts to achieve and support the ideal system. Political marketing is intended as the dissemination of information about candidates, parties, and programs carried out by political actors through certain communication channels which are addressed to a particular segment with the aim of changing insight, knowledge, attitudes and behavior of the community in accordance to the wish of the voters (Damsar, 2010: 226). Analyzing the political activity can produce the exact model of political positioning so that political parties and the public can perform the political education functions and public participation is achieved realistically. Based on the findings by Suyanto, et al (2014: 459-460) is that the constituents prefer legislative candidates based on personal / figures, popularity and capacity / capability of candidates. During this time, the model of political positioning in Indonesia has not been mapped. Therefore, the 
authors analyze the picture of political positioning models based legislative elections regional aspects. This article contains the background, implications, literature review, methodology, result and discussion, conclusion, and reference.

Indonesia is one the democratic country which can be seen from the elections that were held. Legislative election is followed by 12 political parties for positions in legislative City, Provincial and Central level and also choose the local councils. Considering, Indonesia as the Republic of Indonesia (NKRI) and it various culture where the election was held simultaneously. So, it needs appropriate strategies from political parties and political actors in influencing public decision in using their voting rights. Political positioning is how the parties or legislative candidates in influencing voters' decisions to give a different impression (Firmanzah, 2008: 201). Great variety of country and people of Indonesia, so far there was no model of political positioning that can be used precisely by political parties, candidates, and the community. Based on the findings by Suyanto, et al (2014: 460) is that approach to political marketing strategy used by political parties and candidates in the City people to the political pull marketing approach are valuable. Therefore, there's need for analyzing the result of the mapping marketing strategy to determine the exact positioning from the region aspects of the city region, district region and coastal areas.

\section{Literature Reviews}

\subsection{Political Parties and Their Functions}

A political party is a tool for a group of people who have certain political orientations to obtain the power of the government and the people's support. Haerelmen M Ricard (in Affan Gafar, 2004: vii), is that of all the tools ever designed by man to achieve their political goals, perhaps none is more powerful than political parties. It likens that modern politics without political parties is like a fish out of water. Seiler in Firmanzah (2008: 69) defines a political party as an organization that aims to mobilize individuals in a collective action against another group, or form a coalition with the party sitting in government.

Political parties as one of the important democratic institutions, political parties have some major roles, including as a vehicle for political participation of citizens, as a tool of forming political attitudes of citizens through the implementation of political education conducted by the political parties, as a tool of political recruitment to realize healthy regeneration, as a tool of political communication between government and citizens and vice versa, as well as fighting for the interests of marginalized groups which do not have the political resources and power. Furthermore, the function of a political party is a political recruitment (Budiarjo, 2008: 406). It is closely related to the issue of leadership selection, as well as in the internal party where the party requires qualified candidate because it determines the quality of the party so that they can have a greater opportunity to develop themselves in the national leadership. Direct election can be called as democratic politics if it meets a number of principles, which are using the principles that apply in an open political recruitment, such as legislative elections (House of Representatives, Parliament) and the election of the president and vice president, namely the principles of Langsung (direct), Umum (general), Bebas (free), Rahasia (confidential), Jujur (honest) and Adil (fair) (LUBER JURDIL).

\subsection{Linkage of Political Participation in Voters' Decision}

In a strong democracy, participation is not simply to maintain interest, but is a mature public process, which does not claim a truth beyond what is approved by consensus by the citizens.

According to Faulk (2010: 257) "An effective system of democracy is that shows the combination of greater citizen engagement, such as the board of citizens and referendum, representation bodies that are more proportional and reliable in the constitutional context of defending the rights and realize the various types and the level of political participation ".

In this definition, participation is understood as an effort of minority group or one who does not have the reins of power to fight for their interests. The involvement of citizens in the political process is not limited to the formation of a sense of belonging as a part of the political system, but also with regard to the participation system that accommodates the participation of citizens in the political processes that take place.

For a country that adopts a democratic government system, the political parties as a liaison tool between the people and the government so that the political parties should carry out its role and function as democratic political element in order to create national interests and national objectives. As one of them is to form citizens who are responsible and participate in political life as one of the goals of Civic Education which is through political education. Political education in Civic Education in the society (Citizenship Education) by political parties in the society aims to make the public/citizens know and exercise the rights and obligations in any political activity. By knowing the rights and 
obligations as citizens, then realize its political function. According to Quigley (2000) is that civic participation is closely related to the praxis constitutional democracy that depends on an intelligent participation of citizens. This is because the government policies are measured and determined by the decisions of voters and citizens who have the awareness to political participation. Furthermore, according to Suryadi, Karim (2008: 6) is that the political efficacy of citizens / voters' decisions will appear when there was impact in the changes of political system. The political participation of citizens in order to make a change for the better in the process of making public policy, therefore civic knowledge and civic skills are necessary through political education. Political education should be carried out by a political party that is not only limited to the group that has the same ideological because political parties as political organization can put people in positions of political which means it will determine public policies that have broad impact on the interests of the nation.

\subsection{Political Positioning}

Political positioning is an action to embed the image into the minds of voters or constituents so that the product offering of political party and legislative candidates have a distinctive, clear and meaningful position so it can affect the decision in choosing (Firmanzah; 2008: 203). Effective positioning can demonstrate the advantages of each candidate and political party. Positioning indirectly interpreted as a competitor: that competitors can not realize certain bids as well as the party which initiated the positioning. Distinctive, clear and meaningful position from a contestant comes from distinguishing factors possessed by the candidate compared to the other candidates. But not all the differentiating factor which is possessed by each candidate can produce an effective positioning. Lock \& Harris (1996) proposed that political marketing give attention to the process of positioning. Kotler (1997: 262): "Positioning is the act of designing the company's offer so that it occupies a distinct and value placed in the target customer mind".

\section{Methodology}

The approach used in this research is a qualitative approach (Creswell, 2003). Research step determines the political market positioning can determine the voter's decision and bring a civil society based on the analysis of political marketing strategy mapping. The data can be obtained from the documentation of both written and electronic media, in-depth interviews on political parties, legislative candidates, and community. In addition, the data obtained through field observations.

Researchers also seeks to construct and evaluate public perception in a broad context with the possibility of different perspectives. Thus an outline of the data collection techniques in the study of this action are: direct observation, questionnaires, and documents (existing political data sources, mass media, biography, autobiography and the internet).

The location of this research conducted in West Java in particular; rural area and commuter area, because with such a division, can be seen the comparison of political marketing strategies based on the region. While the subject of the research is carried out towards the public and political party leaders. Data were analyzed by Interactive Analysis Model (Miles \& Huberman, 1992), where it consist of analysis data preparation, analysis data sorting, digging deep meaning to the data presenting the data and create a broader interpretation of the meaning of the data.

\section{Key Findings Commuter Area and Rural Area}

\subsection{Commuter Area}

Commuter area represent regions with characteristics of the district in general, which is the urban community or society transition from traditional to modern society. Political marketing approach by parties and their candidates should pay attention to the potential of the local community through a comprehensive approach. The result of political party marketing analysis from the conducted research can be described as follows:

\section{a. Product}

Political product in the form of a political party platform for the community in commuter area has not made as a product that can be offered by a political party by the community. In general, people in this area know political platform only on the ideology that brought by political parties alone. Similar case in urban city, vision, mission and work programs of political parties' presence has not been felt by the public. Socialization done by political parties is still limited to the promise of the program. In determining legislative candidates, the people in this area were doing based on the popularity of candidates promoted by political parties, rather than on capacity and figure persona of the candidate. 


\section{a. Place}

The ease of society to reach the location where the product is offered becomes community own consideration. In accessing the party or candidate profile through the secretariat / winning post allows the distribution of information received by the public more quickly. Attributes of political parties and candidates also contribute to the determination of the selection of legislative candidates.

\section{b. Price}

It's also similar with the public perception in urban city. Funds which is needed to advance into legislative candidates are perceived as not cheap. Legislative candidates must have substantial funds to finance political activities such as campaign finance, pay witness at each polling station, the cost of the promotion, as well as other administrative costs. The amount of funds by legislative candidates, in the public perception of commuter area, turned out to be correlated with the magnitude of the opportunity to be elected because of the use of substantial funds, particularly to organize the campaign, providing social assistance, as well as for the promotion through print and electronic media can increase the popularity and image of the legislative candidates. Aside from the popularity aspect of the candidates, another factor that can determine the public choice psychologically is the figure of candidates with similar characteristics (religion, culture, and race / ethnicity).

Factors that affecting the image of political parties based on society's view of commuter area are more caused by the profile of legislative candidates promoted by political parties, on the other side are also caused by media broadcast factors of coverage on political parties.

\section{c. Promotion}

The use of mass / printed media by political parties and legislative candidates become the most widely used tool for the implementation of the 2014 campaign. Printed media is used by political parties to introduce the candidates they carried, and not infrequently the senior leaders of political parties have also become part of the information submitted to the society. For the candidates, banners, pamphlets, brochures, and billboards become the media in marketing themselves, introducing the work program and political jargon to the public. While social media such as Facebook, Twitter, website and other social media have not been used as the main media for promoting political parties or legislative candidates. While in the internal communication, involvement of community figures or leaders in supporting the parties or legislative candidates give significant contribution to the voters.

Based on the above explanation, if carried out in-depth study of the political marketing strategy in Commuter area, the closest approach with the research result is pull political marketing approach which is combined with push political marketing approach. Pull political marketing is intended to capture the mass through the use of various media, including the social media. Meanwhile the push political marketing is aimed at strengthening the public perception of political parties and their promoted candidates, considering the public perception which is relatively easy to reach a political product (acceptability and visibility of political product). This happens because of the tightly increasing occurrence on political competition. Multiparty system adopted by the Indonesian nation becomes one of the factors. In addition, legislative candidates come with significant amounts because of choosing Parliament on district, provincial, and central level. Therefore, based on that commuter area is not urban areas and not isolated which means middle areas so that the tendency to view the popularity of legislative candidates is higher, although some people in sub urbanalso still use the media.

\subsection{Rural Area}

Rural area becomes the research object because of the characteristics of rural areas is considered to represent the rural community (traditional) in West Java. Analysis of political marketing strategy by political parties and legislative candidates in legislative elections in this region is studied from the aspects of the product, place, price, and promotion are as follows:

\section{a. Product}

Political product in the form of a political party platform (ideology, vision, mission, and work programs) from the results of the study, showed the same perception of the studied. Only a small part of the society in rural area knew about the ideology of political parties which carried their chosen legislative candidates. Moreover, the political platforms such as vision, mission, and work programs of political parties based on the views of the community was not become a political product that can be sold / promoted. Political party's products in the form of legislative 
candidates' personality becomes public primary consideration in determining policy choices, particularly on the figure or persona of legislative candidates. For the communities in this region, figure persona of the legislative candidates turned out to be the dominant factor in determining the choice compared to the image / popularity factor and capabilities of the candidates.

\section{b. Place}

The existence and the ease to reach the secretariat of political parties or the winning post of the legislative candidates by the candidates will also be considered in determining the public choice. People becoming familiar with the figure of legislative candidates is some who due to the visibility factor of political parties' and legislative candidates' attributes in the location of political products marketed.

\section{c. Price}

The usual costly funds for participating in the Democratic Party (legislative election) are also perceived by the people in rural area. Not a small amount of funds must be prepared by the candidates in order to advance and compete in legislative elections. Public's view of the costs incurred by the legislative candidates is directly proportionate to the level of the gained popularity, and this allows the emergence of a greater opportunity to win the competition. The public's psychology in selecting legislative candidates as representative in House of Representatives is more based of the similarity factors on the candidates' profile, i.e. in terms of religion, culture and race / ethnicity. There is comfort, confidence, and pride from the community if they were represented by the figure of legislative candidates who have in common with the community in general. The image of political parties by the public of rural area was percept to be caused more by persona / figure factors of the legislative candidates promoted by the party as compared with the reporting factor by the media.

\section{d. Promotion}

Mass/printed media becomes the most used political product marketing tool by political parties and their promoted candidates and only a small part of it that used social media as political marketing tool. The involvement of public figures or leaders given its own color as a media in marketing the political parties. In addition, the implementation of activities that invite the masses become a factor that can increase the popularity of political parties and their legislative candidates.

Based on the above explanation, if carried out in-depth study of the political marketing strategy in rural area, the approach used by political parties and legislative candidates to win the election is push political marketing approach, i.e. with this is a marketing of political products by an approach to the influential figure, group or organization. How to approach or affect the influential figure or groups in society. In certain communities, especially among the grassroots community, a figure becomes public's preference to determine their choice. This can happen because of the non-participant voters or influential figure, group or organization. The non-participant look at the importance of the people ability and capacity or which political party's work programs that can provide solution to problems of the state and nation when that programs were communicated during the period leading up to elections.

Analysis of two areas related to the political marketing, so that the political marketing is run as it aims to:

1. Making the voters as a political subject, where voters were also asked to specify the political programs and products which are supposed to be done. It means that voters also get political education so that it will bring out a civil society.

2. Make the problems faced by voters as the first step in creating a work program that is offered within the framework of their respective political party ideology. The work program that is in direct contact with the interests of the voters will awaken the sympathy of voters towards the political parties.

3. Marketing politics does not guarantee a win, but to provide the tools to maintain a relationship with voters to build trust and further to gain vote support. 
After analyzing the political marketing of 2014 legislative elections in commuter aea and rural area, the strategy can be mapped based on the region as follows:

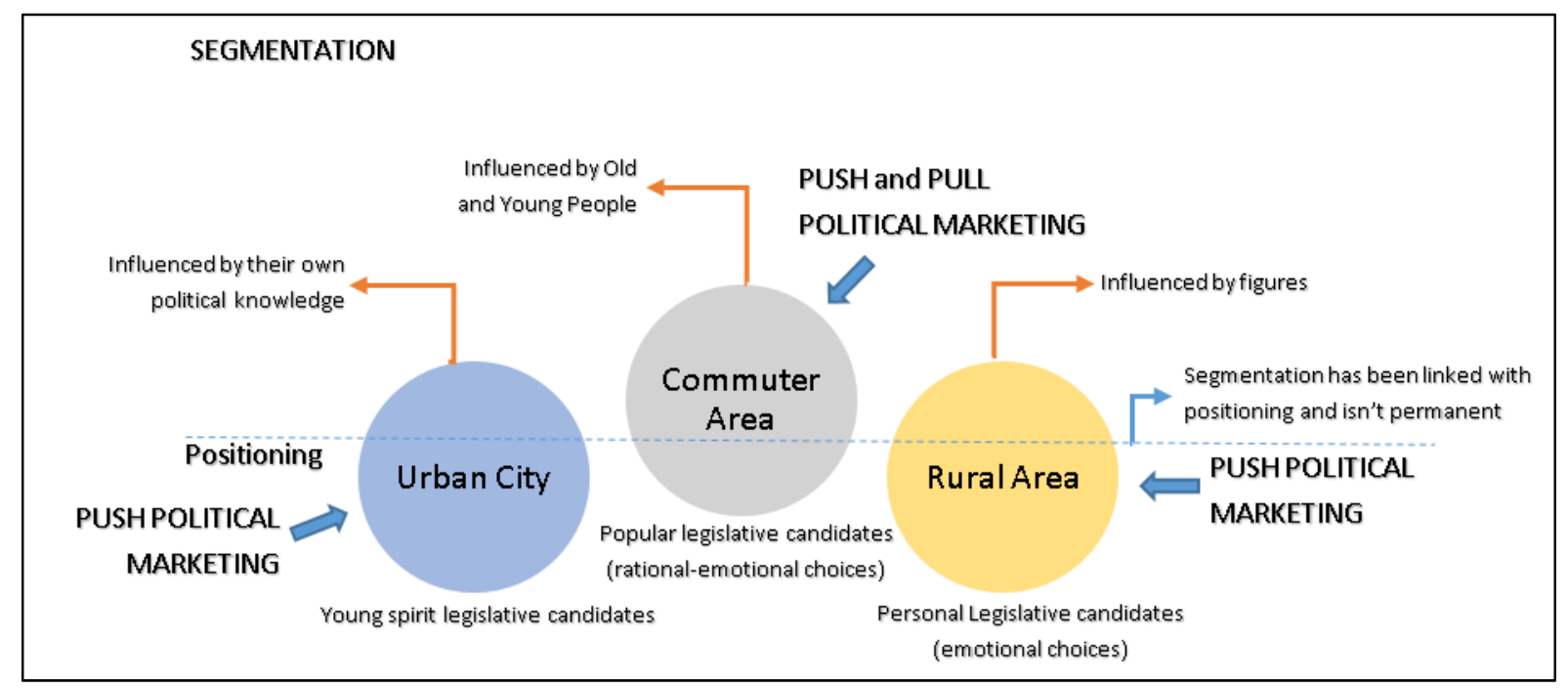

Figure 1. Segmentation, Targeting, Positioning Strategy; Source: result of the analysis

Based on the figure 1. illustrated that the voters segment in commuter area determine their choice based of rational-emotional consideration because of rural area commuter area as non-marginal emphasis areas for all circles. In addition, community/constituent have tended to be modern but still do not have a good political education. People are more likely to see a constituent based on religious and race background. Where they have already started to participate through electronic media to see the capabilities of legislative candidates although still not much, only a portion of the youth circle.

This is in contrast with the condition in rural area which is more inclined to be based on emotional considerations. In commuter area, people were voting because it still influenced by the local leaders and the media used is still traditional because the people live in the coastal area far from the city.

\section{Academic and Practical Implications}

This study presents both academic and practical implications. This research has academic implications for the repertoire of social science, i.e. between political science, marketing science and civic education.

Political science contributed to the science of marketing, especially which is related to political marketing strategy, recognize the two marketing strategies, i.e. pull political marketing and push political. The campaign is carried out by directly visiting the voters. A candidate can go directly visit the homes or residences of the community voters. Simple activities by asking or small dialogue about their daily lives. It is to grow and show empathy and concern about what is perceived or experienced in the community. In Indonesia, this strategy is being commonplace, known as "blusukkan". Therefore, when deciding on the political positioning, marketing science gives contribution, particularly to distinguish the political positioning based on the perspective of territorial from constituencies. In addition, political science and marketing science give contribution to civic education especially that is related to decision-making vote. Citizens should really have civic knowledge, skills and disposition to participate actively so that it giving rise to civil society. According to Quigley (2000), that civic participation is closely related to the praxis constitutional democracy which is depend on an intelligent participation of citizens.

This research is applicative implicate, i.e. political parties and legislative candidates can more easily capture votes in the regency and coastal area through appropriate political positioning. In addition, political parties and candidates can provide appropriate political education for the public so that democratic values remain created.

\section{Conclusion}

1. In commuter area political marketing strategy by political parties and their legislative candidates is tend to use pull political marketing approach and synergized with push political marketing approach. Meanwhile in rural area, 
political marketing strategy by political parties and their candidates is tend to use push political marketing approach.

2. Legislative election political positioning by region are: commuter area is based on rational-emotional, rural area is based on emotional choices.

\section{References}

Beck, Allen, P., \& Jennings, M. K. (1991). Family traditions, political periods, and the development of partisan orientations. Journal of Politics, 53, 742-763.

Budiardjo, Miriam. (2008). Dasar-Dasar Ilmu Politik. Jakarta: Gramedia Pustaka Utama.

Cangara, Hafied. (2009). Komunikasi Politik Konsep Teori Dan Strategi. Jakarta: Rajagrafindo.

Creswell, J.W. (1998). Research Design Qualitative \& Quantitative Approach. London: Publication.

. (2003). Research Design Qualitative \& Quantitative Approach. Penerjemah Achmad Fawaid. Yogyakarta: Pustaka Pelajar.

Dahl, R. (1985). Analisis Politik Modern. Jakarta: Bina Aksara.

Damsar. (2010). Pengantar Sosiologi Politik. Jakarta: Kencana Premedia Goup.

Eep Saefulloh Fatah. (2010). Masalah dan Prospek Demokrasi di Indonesia. Jakarta: Ghalia Indonesia.

Faulk, Keith. (2010). Sosiologi Politik Pengantar Kritis. Bandung: Nusa Media.

Firmanzah. (2011). Mengelola Partai Politik. Jakarta: Yayasan Obor Indonesia. (2008). Mengelola Partai Politik. Jakarta: Yayasan Obor Indonesia.

Kotler, P. dan Armsrong, G. (2007). Prinsip-Prinsip Pemasaran. Edisi 12. Jilid 1. Jakarta: Erlangga.

Miles, Matthew B., \& A. Michael Huberman. (1992). Analisis Data Kualitatif, Buku Sumber tentang Metode-Metode Baru. Jakarta: University of Indonesia.

Quigley, C.N., Buchanan, Jr. J. H., \& Bahmueller, C.F. (2000). Civitas: A Frame Work for Civic Education. Calabasas: Center for Civic Education.

Rohrschneider, R., \& Dalton, R. J. (2002). A global network? Transnational cooperation among environmental groups. The Journal of Politics, 64(2), 510-533. http://dx.doi.org/10.1111/1468-2508.00137

Suyanto, AMA dkk. (2014). Analysis of Political Marketing on Legislative Election. International Conference on Emerging Trends in Academic Research (Etar) 25-26 November 2014). Etar (C 2014 Global Illuminators, Bali, Indonesia.

Suryadi, K. (2008). Pesan Politik di Ruang Publik: Pilihan-pilihan Sumber dan Media bagi Pendidikan Pemilih Vol 2 No.1. Bandung: iski. Bandung: iski. (2007). Perilaku Pemilih Masyarakat Jawa Barat dan Diskurs Calon Independen.Vol 1.No 1. 